\title{
Prevalence of physical inactivity and associated socioeconomic indicators in indigenous Xavante communities in Central Brazil
}

\author{
J. Rodolfo M. Lucena, Carlos E. A. Coimbra Jr., Cosme M. F. Passos da Silva and James R. Welch*
}

\begin{abstract}
Background: Among numerous factors linked to nutrition transition globally, physical inactivity has been identified as a key triggering factor. At present, little is known about physical activity patterns among the Indigenous population in Brazil, which exhibits higher prevalence rates of excess weight than the non-Indigenous population. The present study aims to characterize physical inactivity and associated socioeconomic factors among members of two Xavante villages in Central Brazil.

Methods: This study population included individuals $\geq 18$ years of age residing in Pimentel Barbosa and Etênhiritipá villages, Pimentel Barbosa Indigenous Reserve, Mato Grosso State, Brazil. Physical activity data were collected in February 2011 using an adaptation of the short version of the International Physical Activity Questionnaire (IPAQ). Bivariate and multivariate analyses were conducted to assess associations between variables.

Results: Of a total eligible population of 256 adults, $82.4 \%$ participated in the study. The overall prevalence of physical inactivity was $17.5 \%$, markedly lower than has been described using similar methods for the global and overall Brazilian populations. The prevalence rates of overweight and obesity were 52.1 and $21.8 \%$, respectively. Physical inactivity was more prevalent among males (22.4\%) than females (14.4\%), although this difference was not statistically significant. In the final multivariate model, physical inactivity was more prevalent among individuals $\geq 60$ years of age (PR 2.00, $\mathrm{Cl}_{95 \%}$ 1.02-3.92) and members of households with a television (PR 1.76, $\mathrm{Cl}_{95 \%}$ 1.01-3.05). Individuals in households that planted a garden the prior year were less likely to be physically inactive, although the level of significance was slightly greater than 0.05 (PR 0.55, $\mathrm{Cl}_{95 \%}$ 0.29-1.01).

Conclusions: Our findings suggest that the Xavante pattern of physical inactivity differs from the country's non-Indigenous population in that age-related increases appear later in life and subsistence activities contribute importantly. Physical inactivity among Indigenous peoples in Brazil deserves greater attention due to indications it is not always related to nutrition transition in the same manner as in non-Indigenous populations.
\end{abstract}

Keywords: Brazil, Physical activity, Indigenous peoples, Socioeconomic status, Nutrition transition

* Correspondence: welch@ensp.fiocruz.br

Escola Nacional de Saúde Pública, Fundação Oswaldo Cruz, Leopoldo

Bulhões 1480, Rio de Janeiro, RJ 21041-210, Brazil 


\section{Background}

In recent decades, physical inactivity has come to be viewed as an important global public health issue due to its strong association with the occurrence of obesity and other chronic noncommunicable diseases, such as diabetes mellitus and hypertension, that comprise the nutrition transition complex on a global scale [1-3].

Among the numerous environmental, socioeconomic, educational, and behavioral factors linked to nutrition transition in the world population, decline in physical activity has been identified as a key triggering factor [4-6]. In Brazil, evidence of nutrition transition has been documented since the mid-1970s in conjunction with markedly unequal distribution of obesity and chronic diseases in the population according to income, education, ethnicity, and other sociodemographic indicators [7-9]. Recent surveys of physical activity patterns in Brazil have consistently highlighted the relatively low proportions of adults of both sexes considered to be physically active [10-12].

Within this national context, the Indigenous population in Brazil is particularly vulnerable to the set of conditions associated with nutrition transition, including excess weight during adolescence and young adulthood, as documented by a growing number of studies on obesity epidemiology and associated diseases among different Indigenous ethnic groups in the country [13-17]. According to the most recent national census, the country's Indigenous population in 2010 was nearly 897,000, of which $58 \%$ resided in federally recognized Indigenous reserves [18]. Although comparatively small relative to Brazil's total population, with over 300 ethnic groups it is among the most diverse national Indigenous populations in the world. Recent data from the First National Survey of Indigenous People's Health and Nutrition in Brazil revealed that $46.1 \%$ of Indigenous women are overweight and $15.8 \%$ are obese [19, 20]. As observed globally, important aggravating factors involved in the overall setting of rapid epidemiological and nutritional transition among the country's Indigenous peoples are type 2 diabetes mellitus and hypertension, diseases also associated with physical inactivity [16, 21, 22].

At present, little is known about physical activity patterns among the Indigenous population in Brazil. With the exception of a study by Santos et al. [23], which investigated activity and physical performance patterns in a population-based sample of members of the Khisêdjê ethnic group in the Upper Xingu region of Central Brazil, all other publications address the issue from the perspective of physical exercise and fitness [24-30].

The Xavante (auto-denominated A'uwẽ) people of Central Brazil are characterized by several authors as highly vulnerable to obesity and chronic diseases such as diabetes mellitus and hypertension (see review in [31, 32]). Health and nutrition evaluations conducted in different Xavante communities have suggested that observed elevated frequencies of overweight and metabolic disorders among adults of both sexes are associated with reduced levels of physical activity due to historical socioeconomic changes, emergent forms of work and locomotion that require less energy, as well as rapid increases in the consumption of foods rich in oils and carbohydrates [16, 33-36]. Our previous ethnographic research also suggests that the Xavante attribute this historical transformation in body composition to a combination of dietary and physical activity behavior changes [13]. Nevertheless, physical activity patterns among the Xavante were not previously directly evaluated by systematic means.

The present study aims to characterize physical activity patterns among Xavante individuals living in two villages in the Pimentel Barbosa Indigenous Reserve using a standardized and internationally validated instrument, the International Physical Activity Questionnaire (IPAQ), and investigate their association with selected sociodemographic and nutritional variables.

\section{Methods}

\section{Population}

Permanent contact between the Xavante population now living in the Pimentel Barbosa Indigenous Reserve and the Brazilian federal government was established in the 1940 s as economic expansion policies brought demographic frontiers into closer proximity with Indigenous peoples in eastern and central Mato Grosso State [31, 37-39]. Previously, the Xavante people subsisted through a combination of wild resource procurement and limited agriculture within expansive territories in the cerrado (tropical savanna) landscape of Central Brazil [31, 38-40]. Occupying relatively large villages, often with hundreds of residents, smaller trekking groups also travelled extensively throughout the year to obtain seasonally dispersed resources [39-41]. Significantly greater caloric resources were obtained through collecting than horticulture at most times of the year [40]. As a consequence of territorial circumscription by ranches, reduction of officially recognized Indigenous lands, and governmental promotion of development projects emphasizing mechanized rice agriculture, particularly after the 1960s, the Xavante became increasingly sedentary and reliant on market resources [31, 33, 42]. Worthy of special note are new sources of monetary income, especially public sector salaries and social benefits, that contributed to recent dietary changes and socioeconomic differentiation within villages $[13,31]$.

This study sought to include the entire Xavante population $\geq 18$ years of age residing in two villages, Pimentel Barbosa and Etênhiritipá, located in the Pimentel Barbosa Indigenous Reserve, Mato Grosso State, Brazil. 
Having separated from each other as recently as 2006 and being located less than one kilometer apart, they share widespread genealogical connections and participate in the same local subsistence and regional market economies [39].

\section{Questionnaire and measurements}

Data regarding physical activity patterns were collected during home visits in the presence of Xavante-Portuguese translators. Two skilled translators, one for each village, were previously trained by the interviewer (JRML) during orientation workshops and practice interviews. Interviews were conducted individually with each participant using an adaptation of the short version of the IPAQ instrument available in Portuguese and validated for use in Brazil [43-45]. As recommended by the IPAQ Committee [46], prior to fieldwork and with the help of Xavante interlocutors we adapted this instrument to accommodate specific cultural characteristics of this group and then performed pilot tests to verify that all questions were understood. The principal adaptations implemented were more thorough definitions of vigorous and moderate activities and reformulation of associated examples in order to improve their cultural relevance for Xavante men and women.

Fieldwork was carried out in February 2011 in Pimentel Barbosa and Etênhiritipá villages. All residents $\geq 18$ years old present at the time of fieldwork were invited to participate. IPAQ interviews were conducted at the participant's home with the assistance of a translator. During these individual interviews we also asked a series of questions regarding participants' schooling, sources of income, employment status, and smoking and alcohol consumption frequencies. Additional questions regarding household composition and socioeconomic conditions (monthly income, household food diversity, and presence of durable industrial goods) were conducted separately through interviews with heads of household or other adult residents.

Data regarding diversity of non-traditional foods consumed by household members were collected using a list of 29 foods considered by Xavante consultants to be non-traditional, meaning they were bought in stores (for example, coffee and sugar) or not present in the dietary economy prior to contact with non-Indigenous people (for example, mango fruit and sugarcane). This list of items was developed during research in the previous year and updated immediately prior to this fieldwork. The respondent indicated whether his or her household tended to consume each item rarely/never; sometimes/ seasonally, or frequently/daily. Because this question sought to estimate overall household consumption patterns it did not capture individual variation in nutritional intake within households.
Presence of durable industrial goods was recorded as the number of items owned by residents of the household based on a list of 22 durable industrial goods adapted from instruments used by us in the same population the previous year and updated immediately prior to this fieldwork [13]. This list included motor vehicles, notebooks, generators, televisions, parabolic antennas, video and audio players or recorders, gas stoves, sewing machines, cellular phones, cameras, firearms, fishing nets, and bicycles.

Stature and weight measurements were made by trained researchers, which included three of the authors (JRML, CEAC, and JRW) following Lohman et al. [47], with subjects wearing light apparel and barefoot. Standing height was measured with a free-standing anthropometer (seca model 214, Hamburg, Germany) and recorded to the nearest $0.1 \mathrm{~cm}$. Body weight was measured with a portable digital scale with $100 \mathrm{~g}$ accuracy and $150 \mathrm{~kg}$ maximum capacity (seca model 872, Hamburg, Germany).

\section{Analyses}

Individual physical activity levels were calculated following the IPAQ Committee scoring protocol [48] considering the categories inactive and active. Individuals were classified as inactive if they reported practicing no physical activities or received scores $\leq 600$ MET-minutes/ week. Those classified as active received scores $>600$ MET-minutes/week.

Body Mass Index (BMI) was calculated $\left(\mathrm{kg} / \mathrm{m}^{2}\right)$ and classified in accordance with World Health Organization recommended cutoff points [49]: underweight $(<18.5 \mathrm{~kg} /$ $\mathrm{m}^{2}$ ), normal (18.5 to 24.9 ), overweight (25 to 29.9$)$, and obese (>30).

Several other variables were classified prior to statistical analyses. Participants' age was grouped into three categories $(18-34,35-59$, and $\geq 60$ years) based on our previous ethnographic data regarding physical activity during the Xavante life cycle [50]. Years of schooling was classified in two groups ( $\leq 4$ and $>4$ years). Three additional individual variables were classified using binary (yes or no) values: employed with regular salary, regular or occasional smoker, and at least one alcoholic beverage per week (in response to the question "how many times in a typical week do you usually drink?"). The household variable per capita income for adults (total household income divided by the number of adult residents) was classified in two groups, low and high, based on the median value among households $(\leq \mathrm{R} \$ 220$ and $>$ R $\$ 220$; at the time of research equivalent to $\leq$ US\$ 132 and > US\$ 132) and subsequently distributed to all resident participants. Other household variables were classified using binary values (yes or no) and subsequently distributed to all resident participants: presence 
of electricity, presence of television, presence of motorcycle, presence of bicycle, and food garden planted in prior year.

Diversity of non-traditional foods consumed was calculated for each household by totaling the number of nontraditional food items reported to have been consumed by members of the household (sometimes/seasonally or frequently/daily). As a measure of consumption by the household unit, it is an economic indicator rather than a proxy for individual nutritional intake. Households were classified as consuming low or high diversity of nontraditional foods (diversity scores $<20$ and $\geq 20$, respectively). These values were subsequently distributed to all resident participants.

To assess the potential of selection bias due to non-participation by some village residents due to absence or refusal, we used the chi-squared test for homogeneity (significance level of $p<0.05$ ) to assess differences between the participating and nonparticipating populations for demographic (sex and age) and key socioeconomic (household per capita income for adults, presence of television in household, and whether a household food garden was planted in the prior year) characteristics. The same test and significance level were used to evaluate differences between villages in the outcome variable physical inactivity.

In the initial data analysis, prevalence rates and unadjusted prevalence ratios (PR) were calculated for physical inactivity according to all independent variables. Subsequently, bivariate analyses were conducted using Poisson regression with robust adjustment to evaluate differences in proportions.

We then conducted multivariate analyses using a hierarchical Poisson regression model with robust adjustment of the variance for dichotomous outcomes [51, 52]. Distal household variables (per capita income for adults, electricity, television, motorcycle, bicycle, garden, and non-traditional food diversity) entered the model first, followed by individual variables (BMI, schooling, regular salary, smoking, and drinking) in the second level, and sociodemographic variables (sex and age) in the third. Estimates were adjusted for variables in the same and more distal levels. For each level of the hierarchical framework, variables with $p$-values $<0.25$ in the bivariate analyses were initially retained at each level. Estimates of the effect of backward selection were used at each level, retaining in the final model variables with $p$-values $<0.05$, controlling for variables retained in previous levels and sex [53].

All data were initially consolidated and reviewed for consistency in Microsoft Excel 2007. Statistical analyses were done in STATA/SE for Windows 10.1 (College Station, TX, USA).

\section{Results}

The Xavante adult population $\geq 18$ years residing in Pimentel Barbosa and Etênhiritipá villages numbered 261 individuals. The eligible population was 256 due to five individuals who were pregnant or had physical disabilities. The final study sample consisted of 211 individuals $(82.4 \%$ of the eligible population). Losses were due to absence from the village at the time of the survey $(n=15)$, individuals who declined to participate $(n=25)$, and missing data $(n=5)$. The number of female participants was 104 ( $49.3 \%$ of the sample). The sample was distributed between age groups as follows: 18 to 34 years (58.3\%), 35 to 59 years (30.3\%), and $\geq 60$ years (11.4\%).

No differences were encountered between the participating and non-participating populations for sex $(p=$ $0.301)$, distribution by age group $(p=0.720)$, household per capita income for adults $(p=0.543)$, presence of television in household $(p=0.767)$, and whether a household food garden was planted in the prior year $(p=0.179)$. Analyses showed no significant differences in the distributions of physical inactivity between the two villages $(p$ $=0.384$ ), which were therefore treated as a single population in subsequent analyses.

The overall prevalence of physical inactivity was $17.5 \%$. The prevalence rates of overweight and obesity were 52.1 and $21.8 \%$, respectively. No individuals were underweight.

Table 1 presents prevalence and unadjusted PR with associated confidence intervals of physical inactivity according to individual and household variables. Physical inactivity was more prevalent among males $(22.4 \%)$ than females (14.4\%), although this difference was not statistically significant. Physical inactivity was most prevalent in the age group $\geq 60$ (PR 2.30, $\mathrm{Cl}_{95 \%}$ 1.20-4.44). The prevalence was also greater among individuals in households with a television (PR 1.72, $\mathrm{CI}_{95 \%}$ 0.98-3.03), although this difference was slightly above the significance threshold $(p=0.059)$. Individuals in households that planted a garden the prior year were less likely to be physically inactive (PR 0.48, $\mathrm{CI}_{95 \%}$ 0.26-0.88).

In the final multivariate model (Fig. 1), physical inactivity was more prevalent among individuals $\geq$ 60 years of age (PR 2.00, $\mathrm{CI}_{95 \%}$ 1.02-3.92) and members of households with a television (PR 1.76, $\mathrm{CI}_{95 \%}$ 1.013.05). Individuals in households that planted a garden the prior year were less likely to be physically inactive, although the level of significance was slightly greater than 5 \% (PR 0.55, $\mathrm{CI}_{95 \%}$ 0.29-1.01).

\section{Discussion}

The global prevalence of physical inactivity among adults is estimated to be $31.1 \%$ [3]. This rate for individual countries ranges from 4.7 to $71.9 \%$, with higher income countries tending to be less physically active. 
Table 1 Prevalence of physical inactivity according to individual and household characteristics among Xavante adults $\geq 18$ years, Pimentel Barbosa and Etênhiritipá villages, Mato Grosso, Brazil, February 2011. PR Prevalence ratio, Cl Confidence Interval

\begin{tabular}{|c|c|c|c|c|c|c|}
\hline & & $\mathrm{N}$ & Prevalence of physical inactivity & PR & $\mathrm{Cl}_{95 \%}$ & $p$-value \\
\hline & & & $\%(n)$ & & & \\
\hline Level 1 & Sex & & & & & \\
\hline & Male & 107 & $22.4(22)$ & 1 & (reference) & \\
\hline & Female & 104 & $14.4(15)$ & 0.64 & $(0.36-1.16)$ & $p=0.141$ \\
\hline & Age group & & & & & \\
\hline & 18-34 years & 123 & $16.3(20)$ & 1 & (reference) & \\
\hline & $35-59$ years & 64 & $15.6(10)$ & 0.96 & $(0.48-1.93)$ & $p=0.911$ \\
\hline & $\geq 60$ years & 24 & $37.5(10)$ & 2.30 & $(1.20-4.44)$ & $p=0.012$ \\
\hline Level 2 & BMI & & & & & \\
\hline & Normal & 55 & $21.8(12)$ & 1 & (reference) & \\
\hline & Overweight & 110 & $16.4(18)$ & 0.75 & $(0.39-1.45)$ & $p=0.390$ \\
\hline & Obese & 46 & $19.6(9)$ & 0.90 & $(0.41-1.94)$ & $p=0.782$ \\
\hline & Schooling & & & & & \\
\hline & $\leq 4$ years of study & 122 & $21.3(26)$ & 1 & (reference) & \\
\hline & $>4$ years of study & 89 & $14.6(13)$ & 0.69 & $(0.37-1.26)$ & $p=0.224$ \\
\hline & Employed with regula & & & & & \\
\hline & No & 189 & $18.5(35)$ & 1 & (reference) & \\
\hline & Yes & 22 & $18.2(4)$ & 1.09 & $(0.40-2.60)$ & $p=0.969$ \\
\hline & Regular or occasional & & & & & \\
\hline & No & 121 & $21.5(26)$ & 1 & (reference) & \\
\hline & Yes & 90 & $14.4(13)$ & 0.67 & $(0.37-1.24)$ & $p=0.201$ \\
\hline & At least one alcoholic & e per & & & & \\
\hline & No & 179 & $17.9(32)$ & 1 & (reference) & \\
\hline & Yes & 32 & $21.9(7)$ & 1.22 & $(0.59-2.53)$ & $p=0.587$ \\
\hline Level 3 & Household per capita & for ad & & & & \\
\hline & Low & 109 & $21.1(23)$ & 1 & (reference) & \\
\hline & High & 102 & $15.7(16)$ & 0.74 & $(0.42-1.33)$ & $p=0.316$ \\
\hline & Presence of househol & & & & & \\
\hline & No & 131 & $16.0(21)$ & 1 & (reference) & \\
\hline & Yes & 80 & $22.5(18)$ & 1.40 & $(0.80-2.42)$ & $p=0.241$ \\
\hline & Presence of television & ehold & & & & \\
\hline & No & 131 & $14.5(19)$ & 1 & (reference) & \\
\hline & Yes & 80 & $25.0(20)$ & 1.72 & $(0.98-3.03)$ & $p=0.059$ \\
\hline & Presence of motorcyc & usehol & & & & \\
\hline & No & 141 & $20.6(29)$ & 1 & (reference) & \\
\hline & Yes & 70 & $14.3(10)$ & 0.69 & $(0.36-1.34)$ & $p=0.280$ \\
\hline & Presence of bicycle in & & & & & \\
\hline & No & 126 & $18.3(23)$ & 1 & (reference) & \\
\hline & Yes & 85 & $18.8(16)$ & 1.03 & $(0.58-1.84)$ & $p=0.917$ \\
\hline & Household food garde & ed in $\mathrm{f}$ & & & & \\
\hline & No & 30 & $33.3(10)$ & 1 & (reference) & \\
\hline & Yes & 181 & $16.0(29)$ & 0.48 & $(0.26-0.88)$ & $p=0.018$ \\
\hline
\end{tabular}


Table 1 Prevalence of physical inactivity according to individual and household characteristics among Xavante adults $\geq 18$ years, Pimentel Barbosa and Etênhiritipá villages, Mato Grosso, Brazil, February 2011. PR Prevalence ratio, Cl Confidence Interval (Continued)

\begin{tabular}{llllll}
\multicolumn{2}{c}{ Diversity of non-traditional foods consumed in household } \\
Low & 104 & $17.3(18)$ & 1 & (reference) & \\
High & 107 & $19.6(21)$ & 1.33 & $(0.64-2.01)$ & $p=0.666$
\end{tabular}

However, rates of physical inactivity in some high income countries in North America and Europe appear to be declining in recent decades [54-56]. Studies have also shown that physical inactivity is often more prevalent among women, elderly, ethnic or racial minorities, and urban populations $[3,54,57]$.

According to a recent study, the overall rate of physical inactivity in Brazil is $49.2 \%$, being higher among women (51.6 \%) than men (47.2 \%) [3]. In Brazilian state capitals, physical inactivity rates have declined in the last decade [58]. Other studies conducted among urban populations in Brazil have demonstrated physical inactivity to be associated with higher BMI, age, and socioeconomic status [59-61].

The overall prevalence of physical inactivity among the Xavante from Pimentel Barbosa and Etênhiritipá villages $(17.5 \%)$ was markedly lower than has been described using similar methods for the global and overall Brazilian populations [3]. This difference may derive partially from the observed tendency for rural populations to be less physically inactive than urban populations [57], although this distinction has not been addressed adequately in Brazil, where most studies on physical inactivity have been conducted in urban settings. Additionally, as discussed below, differences between physical activity patterns among the Xavante and the overall Brazilian population may be associated with the distinct sociocultural and economic conditions that characterize this Indigenous group.

Very few studies have addressed physical inactivity patterns among Indigenous peoples globally or in Brazil. Overall, many studies show physical inactivity to be more prevalent among Indigenous women and those in older age, as is reported for non-Indigenous populations. However, physical inactivity prevalence rates vary widely between Indigenous groups. For example, studies using IPAQ instruments show the Inuit in Canada and the Dakota in the United States have physical inactivity rates similar to or below our findings for the Xavante $[62,63]$. Studies using other methodologies, such as pedometers and other questionnaires, have reported physical inactivity rates above $50 \%$ among Aboriginals and Torres Strait Islanders, Australia and Yakut (Sakha) in Siberia, and predominantly Indigenous urban youth (15 to 23 years) in Ghana [64-67].

With very few exceptions [23, 25], most publications address physical activity patterns among Indigenous peoples in Brazil from the perspective of physical exercise and fitness [24, 26-29, 68]. Providing results more comparable to the present study, physical activity patterns assessed by means of the IPAQ among the Terena in Mato Grosso do Sul found $15.1 \%$ of individuals were "irregularly" active [25]. Also, 29.7 \% of Khisêdjê in the Upper Xingu were found to be sedentary or with low physical activity based on pedometry [23]. Although these results used different measures, they suggest that in addition to the Xavante, multiple Indigenous groups show lower physical inactivity prevalence rates than the general Brazilian population.

Our bivariate and multivariate results show physical inactivity was more prevalent among elderly Xavante individuals. Similar patterns are observed globally and in the overall Brazilian population [3, 57], although this contrast was particularly pronounced among the Xavante.
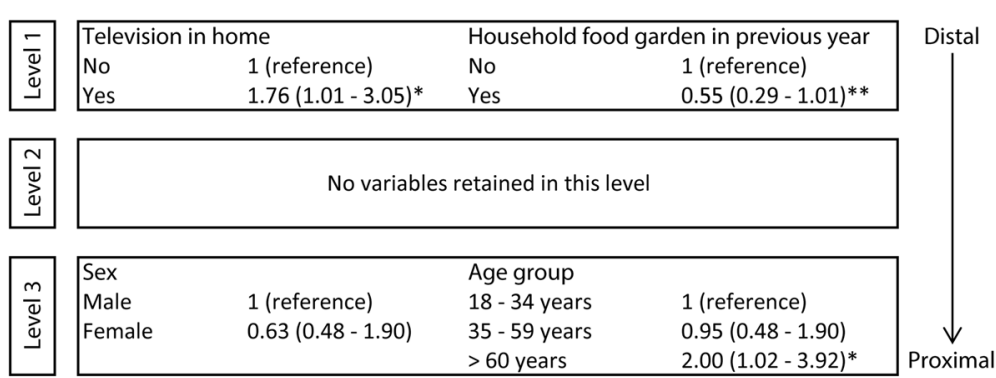

$*$ Significant result $(p<0.05)$
$* * p=0.058$

Fig. 1 Hierarchical model showing prevalence ratios and confidence intervals (in parentheses) for physical inactivity among Xavante adults $\geq 18$ years, Pimentel Barbosa and Etênhiritipá villages, Mato Grosso, Brazil, February 2011. * Significant result $(p<0.05) ;{ }^{* *} p=0.058$ 
Although the inverse association between age and physical activity is well established globally and shown to have biological causes [69], multiple studies show rate of decline to be much greater during adolescence than during adulthood [70]. Among the Xavante, however, the greatest difference was observed among individuals $\geq 60$ years of age (37.5 \%) as compared to those 18-34 (16.3\%) and 35-59 $(15.6 \%)$. This pattern may be associated with the importance in Xavante society of subsistence and work related activity, which remains elevated well into adulthood. Xavante men and women continue to produce food and resources, in large measure by means of physical labor, throughout their lives due to ongoing responsibility for the wellbeing of their children, grandchildren, and great grandchildren. As in other Indigenous societies in Brazil [71], it is only relatively late in life that many elderly Xavante decrease their participation in such subsistence activities as gardening, collecting, hunting, and fishing, receiving subsistence support from their in-laws and other relatives.

Physical inactivity among the Xavante was also less prevalent among individuals living in households that planted a food garden during the previous year (PR 0.55 ), although the significance of this difference was slightly more than $5 \%$. Gardening is a traditional activity among this ethnic group which intensified in the 1970s and 1980s due to a federal development project aiming to transform the Xavante into commercial rice agriculturalists [31, 39]. The project was a decided failure, serving to increase Xavante reliance on external resources and transforming their dietary economy base from collecting, hunting, and fishing in conjunction with limited horticulture to rice. Although most households plant gardens every year, some do not because they have access to the financial resources to buy food in nearby towns or acquire food from relatives and neighbors through trade and reciprocity. The observed difference in physical inactivity prevalence rates according to whether one's household planted a garden suggest that this subsistence activity contributes importantly to the overall physical activity pattern in the community. Other activities such as collecting and hunting may also contribute to this profile, although these were not assessed in the present study.

A strong relationship exists between television watching and physical inactivity, especially among children [72]. In the present study, presence of a television in the household was used as a proxy for television watching. Despite this measure being less sensitive, Xavante individuals living in households with a television presented significantly greater prevalence of physical inactivity (PR 1.76) in the final model. Televisions powered by generators existed in the study villages for at least a decade before our fieldwork, but became more common since
2007 with increased reliability of energy sources and greater access to disposable income. Although individuals within households watch television with different degrees of frequency, it is not uncommon to observe entire families and visitors seated throughout these singleroom dwellings watching the news, soap operas, or sports games on television. Even greater numbers of households acquired televisions after the first grid electrical lines were installed in the village in late 2011 through the federal program Luz Para Todos ("Electricity for All"), but possible impacts were not reflected in our analyses and results from February 2011.

Our results did not show a significant difference in physical inactivity prevalence between men and women. Although one recent study did find such a difference among the general Brazilian population [3], another based on a nationwide sample also found no significant difference between the sexes [73], possibly due to the long form IPAQ including questions about household activities. Our adaptation of the short form IPAQ included culturally appropriate and gender specific examples of vigorous, moderate, and light physical activities in order to facilitate recollection by all respondents, which may have contributed to this lack of association. Among the Xavante, subsistence and leisure activities are highly differentiated by gender $[35,74,75]$. For example, whereas both men and women work in gardens, they consider hunting and collecting to be men's and women's activities, respectively. Also, both sexes participate in such recreational activities as soccer and traditional $\log$ races, but they often do so separately and with different degrees of frequency. Consistent with these observations, our data show that vigorous activities contributed more to the total physical activity rate of Xavante men while moderate activity rates contributed more to those of women. Nevertheless, these differences did not result in significantly different physical inactivity prevalence rates in the present study.

Numerous studies among Indigenous peoples globally and in Brazil have shown an association between physical inactivity and body composition, as measured by BMI or other proxies [23, 63, 65, 76-78]. In the present study, no significant relationship was encountered between physical inactivity and BMI. Although this finding potentially could be related to the indirect nature of this proxy for adiposity, as suggested in a study with similar results [62], a previous study in a different Xavante community found BMI to be highly correlated with other more direct anthropometric measures [79]. Consequently, our observed lack of association may be due to other limitations of the study, such as the crosssectional study design, imprecision of the IPAQ instrument, and relatively small sample size. 
The IPAQ instrument is widely used to assess physical inactivity in geographically disperse and culturally distinct populations due to its efficacy for epidemiological studies [45], as well as its low cost, adaptability, and advantages for comparability between studies [12]. However, the short form of this questionnaire consistently overestimates physical activity due to over reporting by interviewees [80-82]. Among the Xavante, over reporting was evident in some responses and contributed to overestimation of moderate and vigorous activities for some individuals. Although recall was also a problem, we perceived that many respondents had difficulty transforming their memories of physical activities into chronological time estimations, especially because many Xavante do not use watches and instead estimate time by other means, such as position of the sun.

Another limitation of the study was the short time window within which interviews were conducted. Differently from many urban populations, physical activities among the Xavante vary substantially in accordance with village-wide activities, such as ceremonial activities, group collecting and hunting excursions, and the domestic gardening cycle. Consequently, it is not uncommon for most women or men of certain age groups to be engaged in similar activities at the same time. Consequently, short periods of field research may result in documenting skewed physical activity patterns for large segments of the population. The data presented here were collected during one of three attempts, the other two of which were unsuccessful due to village-wide hunting and ceremonial activities. Similarly, the crosssectional study design is also a limitation because individual variation in physical inactivity was not assessed for periods longer than one week and seasonal variation was not captured. This limitation may have contributed to the lack of associations encountered between physical inactivity and independent variables reflecting longer term conditions, such as BMI, schooling, and employment status.

\section{Conclusion}

The factors associated with physical inactivity among Indigenous peoples involve complex dynamics related to recent transformations in their social and economic systems and ecological settings in conjunction with cultural dimensions. Our results show that physical inactivity is less prevalent among the Xavante from Pimentel Barbosa and Etênhiritipá villages than the national population, even though they are shown to suffer from higher rates of excess weight. This point and our finding of no significant association between physical inactivity and BMI suggest that more research is necessary to fully understand the link between physical activity, nutrition, and health outcomes among the Xavante. At present, physical activity and inactivity receive scarce mention in the national politics of health and education of Indigenous peoples in Brazil. Our findings show that physical activity patterns are related to work and leisure behavior, suggesting that further research, as well as health and education interventions, should address both.

\section{Abbreviations \\ BMI, Body mass index; CEP, Research Ethics Committee; Cl, Confidence interval; CONEP, National Research Ethics Committee; FUNAI, National Indian Foundation; IPAQ, International Physical Activity Questionnaire; PR, Prevalence ratio}

\section{Acknowledgements}

The authors thank the residents of Pimentel Barbosa and Etênhiritipá villages for authorizing the study and all participants for their support and patience during data collection. Translation assistance was provided by Eugênio Tsere'ute and Vinícius Sidiwê Supretaprã. This study was conducted as part of a larger research program regarding Xavante health and nutrition. We thank members of this research team, especially Aline A. Ferreira, Maurício G. Oliveira, Verônica M. Zembrzuski, and Xavante assistants Francisco Sitomowẽ and Azevedo Prépe, for providing support while researchers took the anthropometry measurements reported here. Additionally, Felipe G. Tavares generously made available his calculations regarding household food diversity and household goods.

\section{Funding}

Financial support was received from the Brazilian National Research Council (grants Programa Estratégico de Apoio à Pesquisa em Saúde - Fundação Oswaldo Cruz no. 403569/2008-7 and Universal no. 475674/2008-1) and the National School of Public Health (Inova-ENSP research program).

\section{Availability of data and materials}

Due to the small size of the population, data will not be shared in order to prevent violating the confidentiality of individuals and households, who may be identifiable by response variables in the absence of explicitly identifying information

\section{Authors' contributions}

JRML, CEAC, and JRW participated in the conception of the study. JRML, CEAC, and JRW participated in data collection. JRML and CMFPS performed data analysis. JRML, CEAC, and JRW contributed to the interpretation of data and wrote the paper. All authors participated in the revision of the manuscript and approved the version submitted for publication.

\section{Competing interests}

The authors declare that they have no competing interests.

\section{Consent for publication}

Not applicable.

\section{Ethics approval and consent to participate}

The study was approved by the Research Ethics Committee (Comitê de Ética em Pesquisa - CEP) at the National School of Public Health, Oswaldo Cruz Foundation; by the National Research Ethics Committee (Comissão Nacional de Ética em Pesquisa - CONEP), Brazilian National Health Council; and by the National Indian Foundation (Fundação Nacional do Índio - FUNAI), Brazilian Ministry of Justice. The study was publicly presented to and approved by the leadership councils (warã) of the two study villages according to traditional Xavante protocols. Collective Informed Consent was obtained at these meetings. Any household or guardian could decline to participate at any moment. 


\section{References}

1. Bauman A, Finegood DT, Matsudo V. International perspectives on the physical inactivity crisis. Structural solutions over evidence generation? Prev Med. 2009:49:309-12.

2. Popkin BM, Adair LS, Ng SW. Global nutrition transition and the pandemic of obesity in developing countries. Nutr Rev. 2012;70:3-21.

3. Hallal PC, Andersen LB, Bull FC, Guthold R, Haskell W, Ekelund U, et al. Global physical activity levels: surveillance progress, pitfalls, and prospects. Lancet. 2012;380:247-57

4. World Health Organization (WHO). The World Health Report 2002: reducing risks, promoting healthy life. Geneva: World Health Organization; 2002.

5. Brownson RC, Boehmer TK, Luke DA. Declining rates of physical activity in the United States: what are the contributors? Annu Rev Public Health. 2005; 26:421-43.

6. Rind $\mathrm{E}$, Jones A. Declining physical activity and the socio-cultural context of the geography of industrial restructuring: a novel conceptual framework. J Phys Act Health. 2014;11:683-92.

7. Monteiro CA, Benício MHDA, Conde WL, Popkin BM. Shifting obesity trends in Brazil. Eur J Clin Nutr. 2000;54:342-46.

8. Monteiro CA, Conde WL, Popkin BM. The burden of disease from undernutrition and overnutrition in countries undergoing rapid nutrition transition: a view from Brazil. Am J Public Health. 2004;94:433-34.

9. Goulart AC, Silva FM, Castro I, Lotufo PA, Cardoso MA, Benseñor IM. Race and parity as risk factors for obesity among low-income women in Brazil. Nutr Res. 2007:27:27-32.

10. Salvo D, Rei RS, Hino AAF, Hallal PC, Pratt M. Intensity-specific leisure time physical activity and the built environment among Brazilian adults: a best-fit model. J Phys Act Health. 2015;12:307-18.

11. Dumith SC. Physical activity in Brazil: a systematic review. Cad Saude Publica. 2009;25 Suppl 3:S415-26.

12. Monteiro CA, Conde WL, Matsudo SM, Matsudo VR, Bonsenor IM, Lotufo PA A descriptive epidemiology of leisure-time physical activity in Brazil, 19961997. Rev Panam Salud Publica. 2003;14:246-54.

13. Welch JR, Ferreira AA, Santos RV, Gugelmin SA, Werneck G, Coimbra Jr CEA Nutrition transition, socioeconomic differentiation, and gender among adult Xavante Indians, Brazilian Amazon. Hum Ecol. 2009:37:13-26.

14. Lourenço AEP, Santos RV, Orellana JDY, Coimbra Jr CEA. Nutrition transition in Amazonia: obesity and socioeconomic change in the Suruí Indians from Brazil. Am J Hum Biol. 2008;20:564-71.

15. Meyerfreund D, Gonçalves C, Cunha R, Pereira AC, Krieger JE, Mill JG. Agedependent increase in blood pressure in two different Native American communities in Brazil. J Hypertens. 2009;27:1753-60.

16. Dal Fabbro AL, Franco LJ, Silva AS, Sartorelli DS, Soares LP, Franco LF, Kuhn PC, Moises RS, Vieira-Filho JPB. High prevalence of type 2 diabetes mellitus in Xavante Indians from Mato Grosso, Brazil. Ethn Dis. 2014;24:35-40.

17. Santos RV. Crescimento físico e estado nutricional de populações indígenas brasileiras. Cad Saude Publica. 1993;9(Supl 1):46-57.

18. Instituto Brasileiro de Geografia e Estatística (IBGE). Censo demográfico 2010: características gerais dos indígenas, resultados do universo. Rio de Janeiro: IBGE; 2010.

19. Coimbra Jr CEA, Santos RV, Welch JR, Cardoso AM, Souza MC, Garnelo L, Rassi E, Foller M-L, Horta BL. The First National Survey of Indigenous People's Health and Nutrition in Brazil: rationale, methodology, and overview of results. BMC Public Health. 2013;13:52.

20. Anderson I, Robson B, Connolly M, Al-Yaman F, Bjertness E, King A, Tynan M, Madden R, Bang A, Coimbra Jr CEA, Pesantes MA, Amigo H, Andronov S, Armien B, Obando DA, Axelsson P, Bhatti ZS, Bhutta ZA, Bjerregaard P, Bjertness MB, Briceño-León R, Broderstad AN, Bustos P, Chongsuvivatwong V, Chu J, Deji, Gouda J, Harikumar R, Htay TT, Htet AS, Izugbara C, Kamaka M, King M, Kodavanti MR, Lara M, Laxmaiah A, Lema C, Taborda AML, Liabsuetrakul T, Lobanov A, Melhus M, Meshram I, Miranda JJ, Mu TT, Nagalla B, Nimmathota A, Popov Al, Poveda AM, Ram F, Reich H, Santos RV, Sein AA, Shekhar C, Sherpa LY, Skold P, Tano S, Tanywe A, Ugwu C, Ugwu F, Vapattanawong P, Wan X, Welch JR, Yang G, Yang Z, Yap Z. Indigenous and tribal peoples' health (The Lancet-Lowitja Institute Global Collaboration): a population study. Lancet. 2016; Online First. http://dx.doi.org/10.1016/S01406736(16)00345-7

21. Gimeno SG, Rodrigues D, Cano EN, Lima EE, Schaper M, Pagliaro H, et al. Cardiovascular risk factors among Brazilian Karib indigenous peoples: upper Xingu, Central Brazil, 2000-3. J Epidemiol Community Health. 2009;63:299-304
22. Oliveira GF, Oliveira TRR, Ikejiri AT, Andraus MP, Galvao TF, Silva MT, et al. Prevalence of hypertension and associated factors in an Indigenous community of Central Brazil: a population-based study. PLoS One. 2014:9:e86278.

23. Santos KM, Tsutsui MLS, Galvão PPO, Mazzucchetti L, Rodrigues D, Gimeno SGA. Grau de atividade física e síndrome metabólica: um estudo transversal com indígenas Khisêdjê do Parque Indígena do Xingu, Brasil. Cad Saude Publica. 2012;28:2327-38.

24. Almeida AJM, Almeida DMF, Grando BS. As práticas corporais e a educação do corpo indígena: a contribuição do esporte nos jogos dos povos indígenas. Rev Bras Ciênc do Esporte. 2010;32:59-74.

25. Souza AF. Atividade diária e (in) atividade física na sociedade indígena Terena: aldeias Buriti e Córrego do Meio. Master thesis (Physical Education). Campinas: Universidade Estadual de Campinas; 2008.

26. Vinha M. Corpo-sujeito Kadiwéu: jogo e esporte. Master thesis (Physical Education). Campinas: Universidade Estadual de Campinas; 2004.

27. Dieckert J, Mehringer J. A corrida de toras no sistema cultural dos índios brasileiros Canela. Rev Bras Ciênc do Esporte. 1994;15:166-80.

28. Nascimento Jr JRA, Faustino RC. Jogos indígenas: o futebol como esporte tradicional Kaingáng. Pensar a Prática. 2009;12:1-12.

29. Bankoff ADP, Marchi-Neto FL, Cruz EM, Moreira SM, Zamai CA. Estudo da aptidão física relacionada à saúde de diversos grupos étnicos indígenas brasileiros. Movimento e Percepção. 2007;7:208-23.

30. Vichi FL, Souza JM. The physical capacity of different professional groups of Brazilian Amazonians, studied by cycle ergometry. Acta Amazon. 1978:8:381-86

31. Coimbra Jr CEA, Flowers NM, Salzano FM, Santos RV. The Xavánte in transition: health, ecology, and bioanthropology in Central Brazil. Ann Arbor: University of Michigan Press; 2002.

32. Coimbra Jr CEA, Santos RV, Welch JR. A half-century portrait: health transition in the Xavante Indians from Central Brazil. In: Brondízio ES, Moran EF, editors. Human-environment interactions: current and future directions. New York: Springer; 2012. p. 1-35.

33. Gugelmin SA, Santos RV. Ecologia humana e antropometria nutricional de adultos Xavánte, Mato Grosso, Brasil. Cad Saude Publica. 2001; 17:313-22.

34. Leite MS, Santos RV, Gugelmin SA, Coimbra Jr CEA. Crescimento físico e perfil nutricional da população indígena Xavánte de Sangradouro-Volta Grande, Mato Grosso, Brasil. Cad Saude Publica. 2006;22:265-76.

35. Welch JR. Xavante ritual hunting: anthropogenic fire, reciprocity, and collective landscape management in the Brazilian cerrado. Hum Ecol. 2014; 42:47-59.

36. Soares LP, Dal Fabbro AL, Silva AS, Sartorelli DS, Franco LF, Kuhn PC, Moises RS, Vieira-Filho JP, Franco LJ. Prevalence of metabolic syndrome in the Brazilian Xavante indigenous population. Diabetol Metab Syndr. 2015;7:105.

37. Garfield S. Indigenous struggle at the heart of Brazil: state policy, frontier expansion, and the Xavante Indians, 1937-1988. Durham: Duke University Press; 2001.

38. Lopes da Silva A. The Akwe-Xavante in history at the end of the 20th century. J Lat Am Caribb Anthropol. 1999;4:212-37.

39. Welch JR, Santos RV, Flowers NM, Coimbra Jr CEA. Na primeira margem do rio: território e ecologia do povo Xavante de Wedezé. Rio de Janeiro: Museu do Indio/FUNAl; 2013.

40. Maybury-Lewis D. Akwẽ-Shavante society. Oxford: Clarendon; 1967.

41. Santos RV, Flowers NM, Coimbra Jr CEA, Gugelmin SA. Tapirs, tractors, and tapes: economy and ecology of the Xavánte Indians of Central Brazil. Hum Ecol. 1997:25:545-66.

42. Flowers NM. Seasonal factors in subsistence, nutrition, and child growth in a Central Brazilian community. In: Hames RB, Vickers WT, editors. Adaptive responses of native Amazonians. New York: Academic; 1983. p. 357-90.

43. Questionário Internacional de Atividade Física: Versão Curta. Centro de Estudos do Laboratório de Aptidão Física de São Caetano do Sul, São Caetano do Sul, Brazil. http://www.celafiscs.org.br/index.php/contribuicoesa-ciencia. Accessed 19 Fev 2015.

44. Matsudo S, Araújo T, Matsudo V, Andrade D, Andrade E, Oliveira L, et al. Questionário Internacional de Atividade Física (IPAQ): estudo de validade e reprodutibilidade no Brasil. Rev Atividade Fís Saúde. 2001;6:5-18.

45. Craig $C L$, Marshall AL, Sjöström M, Bauman AE, Booth ML, Ainsworth BE, et al. International physical activity questionnaire: 12-country reliability and validity. Med Sci Sports Exerc. 2003:35:1381-95. 
46. Cultural adaptation. IPAQ International Physical Activity Questionnaire. https://sites.google.com/site/theipaq/cultural-adaptation. Accessed 21 Jan 2016.

47. Lohman TG, Roche AF, Martorell R. Anthropometric standardization reference manual. Champaign: Human Kinetics Books; 1988.

48. IPAQ scoring protocol. IPAQ International Physical Activity Questionnaire. https://sites.google.com/site/theipaq/scoring-protocol. Accessed 21 Jan 2016

49. World Health Organization (WHO). Growth standards: length/height-for-age, weight-for-age, weight-for-length, weight-for-height and body mass indexfor-age: methods and development. Geneva: World Health Organization; 2006.

50. Welch JR. Age and social identity among the Xavante of Central Brazil. Ph.D. dissertation (Anthropology). New Orleans: Tulane University; 2009.

51. Barros A, Hirakata V. Alternatives for logistic regression in cross-sectional studies: an empirical comparison of models that directly estimate the prevalence ratio. BMC Med Res Methodol. 2003;3:21.

52. Coutinho LMS, Scazufca M, Menezes PR. Métodos para estimar razão de prevalência em estudos de corte transversal. Rev Saude Publica. 2008:42:992-98

53. Victora CG, Huttly SR, Fuchs SC, Olinto MT. The role of conceptual frameworks in epidemiological analysis: a hierarchical approach. Int J Epidemiol. 1997;26:224-27.

54. Kruger J, Ham SA, Kohl HW. Trends in leisure-time physical inactivity by age, sex, and race/ethnicity-United States, 1994-2004. Morb Mortal Weekly Rep. 2005;54:991-94

55. Craig CL, Russell SJ, Cameron C, Bauman A. Twenty-year trends in physical activity among Canadian adults. Can J Public Health. 2004;95:59-63.

56. Barengo NC, Nissinen A, Tuomilehto J, Pekkarinen $\mathrm{H}$. Twenty-five-year trends in physical activity of 30- to 59-year-old populations in eastern Finland. Med Sci Sports Exerc. 2002;34:1302-07.

57. Guthold R, Ono T, Strong KL, Chatterji S, Morabia A. Worldwide variability in physical inactivity: a 51-country survey. Am J Prev Med. 2008;34:486-94.

58. Mielke G, Hallal PC, Malta D, Lee I-M. Time trends of physical activity and television viewing time in Brazil: 2006-2012. Int J Behav Nutr Phys Act. 2014;11:101

59. Thomaz PMD, Costa THM, Silva EF, Hallal PC. Fatores associados à atividade física em adultos, Brasília, DF. Rev Saude Publica. 2010:44:894-900.

60. Lopes JA, Longo GZ, Peres KG, Boing AF, Arruda MP. Fatores associados à atividade física insuficiente em adultos: estudo de base populacional no sul do Brasil. Rev Bras Epidemiol. 2010;13:689-98.

61. Baretta E, Baretta M, Peres KG. Nível de atividade física e fatores associados em adultos no Município de Joaçaba, Santa Catarina, Brasil. Cad Saude Publica. 2007;23:1595-602.

62. Hopping BN, Erber E, Mead E, Roache C, Sharma S. High levels of physical activity and obesity co-exist amongst Inuit adults in Arctic Canada. J Hum Nutr Diet. 2010;23:110-14.

63. Duncan GE, Goldberg J, Buchwald D, Wen Y, Henderson JA. Epidemiology of physical activity in American Indians in the Education and Research Towards Health Cohort. Am J Prev Med. 2009;37:488-94.

64. Trewin D, Madden R. The health and welfare of Australia's Aboriginal and Torres Strait Islander peoples. Canberra: Australian Bureau of Statistics and Australian Institute of Health and Welfare; 2005.

65. Wilson HJ, Leonard WR, Tarskaia LA, Klimova TM, Krivoshapkin VG, Snodgrass JJ. Do physical activity and sedentary behavior relate to cardiometabolic risk factor clustering in indigenous Siberian adults? Am J Hum Biol. 2015;27:149-56.

66. Afrifa-Anane E, Agyemang C, Codjoe SNA, Ogedegbe G, Aikins ADG. The association of physical activity, body mass index and the blood pressure levels among urban poor youth in Accra, Ghana. BMC Public Health. 2015; 15:269.

67. Noble NE, Paul CL, Turner N, Blunden SV, Oldmeadow C, Turon HE. A crosssectional survey and latent class analysis of the prevalence and clustering of health risk factors among people attending an Aboriginal Community Controlled Health Service. BMC Public Health. 2015;15:666.

68. Vianna FLB. Boleiros do cerrado: índios Xavantes e o futebol. São Paulo: Annablume; 2008.

69. Ingram DK. Age-related decline in physical activity: generalization to nonhumans. Med Sci Sports Exerc. 2000;32:1623-29.

70. Sallis JF. Age-related decline in physical activity: a synthesis of human and animal studies. Med Sci Sports Exerc. 2000;32:1598-600.
71. Borghi AC, Carreira L. Condições de vida e saúde do idoso indígena Kaingang. Escola Anna Nery: Revista de Enfermagem. 2015;19:511-17.

72. Marshall SJ, Biddle SJH, Gorely T, Cameron N, Murdey I. Relationships between media use, body fatness and physical activity in children and youth: a meta-analysis. Int J Obes Relat Metab Disord. 2004;28:1238-46.

73. Hallal PC, Victora CG, Wells JCK, Lima RC. Physical inactivity: prevalence and associated variables in Brazilian adults. Med Sci Sports Exerc. 2003;35:1894-900.

74. Graham LR. Genders of Xavante ethnographic spectacle: cultural politics of inclusion and exclusion in Brazil. In: Graham LR, Glenn Penny H, editors. Performing indigeneity: global histories and contemporary experiences. Lincoln: University of Nebraska Press; 2014. p. 305-50.

75. Welch JR. Learning to hunt by tending the fire: Xavante youth, ethnoecology, and ceremony in Central Brazil. J Ethnobiol. 2015;35:183-208.

76. Li M, Campbell S, McDermott R. Y-Glutamyltransferase, obesity, physical activity, and the metabolic syndrome in Indigenous Australian adults. Obesity. 2009;17:809-13.

77. Bersamin A, Wolsko C, Luick BR, Boyer BB, Lardon C, Hopkins SE, Stern JS, Zidenberg-Cherr S. Enculturation, perceived stress, and physical activity: implications for metabolic risk among the Yup'ik - the Center for Alaska Native Health Research Study. Ethn Health. 2013;19:255-69.

78. Egeland GM, Denomme D, Lejeune P, Pereg D. Concurrent validity of the International Physical Activity Questionnaire (IPAQ) in an liyiyiu Aschii (Cree) community. Can J Public Health. 2008;99:307-10.

79. Gugelmin SA, Santos RV. Use of body mass index to evaluate the nutritional status of Xavánte Indigenous adults, Sangradouro-Volta Grande, Mato Grosso State, Central Brazil. Cad Saude Publica. 2006:22:1865-72.

80. Rzewnicki R, Auweele $\mathrm{V}$, Bourdeaudhuij ID. Addressing overreporting on the International Physical Activity Questionnaire (IPAQ) telephone survey with a population sample. Public Health Nutr. 2003;6:299-305.

81. Lee $P$, Macfarlane D, Lam T, Stewart S. Validity of the international physical activity questionnaire short form (IPAQ-SF): a systematic review. Int J Behav Nutr Phys Act. 2011:8:115.

82. Hallal PC, Victora CG. Reliability and validity of the International Physical Activity Questionnaire (IPAQ). Med Sci Sports Exerc. 2004;36:556.

\section{Submit your next manuscript to BioMed Central and we will help you at every step:}

- We accept pre-submission inquiries

- Our selector tool helps you to find the most relevant journal

- We provide round the clock customer support

- Convenient online submission

- Thorough peer review

- Inclusion in PubMed and all major indexing services

- Maximum visibility for your research

Submit your manuscript at www.biomedcentral.com/submit
Biomed Central 